\title{
Exploring the readiness of Nigerian Colleges of Education toward Pre- service Teacher Preparation for Technology Integration
}

\author{
Sani Alhaji Garba, Christy Ayi Alademerin \\ School of Educational Studies, Universiti Sains Malaysia \\ Malaysia
}

\begin{abstract}
The influence of digital technology in society has made ICT literacy a basic requirement needed by all to survive the challenge of living in the $21^{\text {st }}$ Century. The education industry is now faced with the challenge of helping learners to acquire this literacy. Coping with this challenge requires breeding teachers' with high level of proficiency in ICT literacy and competence. This study investigates the readiness of Nigerian Colleges of Education toward breeding social studies teachers with ICT literacy and competence. It is an exploratory conceptual study that is literature-based (document-based qualitative study approach). The study therefore explore literature to find out the benefit of ICT integration in social studies teacher education; the preparedness of Nigerian Colleges of Education for ICT integration; and the implications of the current state of technology integration on social studies objectives. Findings from this study indicated that, Colleges of education in Nigeria are not readily prepared for effective technology integration; mисh is still needed in terms of infrastructure and manpower development.
\end{abstract}

\section{Introduction}

Advancement in computer and internet technology has over the year's transformed human society, making the world a global village in the present information age. The impact of this advancement is felt in all spheres of human endeavour as reflecting in our socio-economic, political and to some extent the education industry [1]. Use of Information and Communication Technology (ICT) has now become an integral part of the human society [2]. This development has challenged the traditional role of the education sector in human society. Now, the education industry is faced with the challenge of equipping the learner with: technology and information literacy; problem- solving skills; critical reasoning; and the ability to use digital technology in accessing and utilising information for problem-solving in addition to knowledge of subject's content. These knowledge components often described as ICT-literacy has become part of the basic labour requirement in knowledge driven societies; and a necessary foundation for higher education and professional development. This development is necessitating a lot of changes in the education industry evolutionary and revolutionary in an attempt to cope with the emerging challenge of ICT integration in education.

To effectively cope with this emerging challenge of equipping the learner with functional knowledge that bears relevance to the present need of the information (ICT) age, the education industry need to be transformed at all levels. Such a transformation need to reflect on meaningful changes in infrastructure, facilities, curriculum and pedagogical practices. The transformational changes must be directed towards: facilitating the integration of ICT in the curricular content of all subject/disciplines and at all levels of learning; the utilization of ICT equipment in pedagogical practices and other educational practices as applicable to schools, colleges and universities. This would improve teachers' efficacy, enhance teaching and learning while developing learners competence in the use of information technology [3]; [4]. The philosophical basis of such desirable changes must be considered in the interest of the school child who would face the challenge of being engaged with the use of ICT industrially and for his day to day living as an adult in the society [5].

However, the success of such desirable transformation is to a large extent dependent on teachers' ability, efficiency and competence in the use of ICT equipment for personal and educational purposes [6]; [7]. Thus, how competent are teachers in this respect? Preparing pre-service teachers' towards acquiring this competence that can 
facilitates or undermines the ability of the education industry in preparing the school child for the challenge of survival in knowledge driven societies has become an issue of concern. On the other hand, ensuring the competence of pre-service teachers' in the use of ICT materials for educational purposes (as potential teachers') rest upon the preparedness, competence, and commitment of teacher educators, the education faculties and other teacher training institutions. How competent, committed and prepared are teacher educators in Nigerian Colleges of Education? To what extent is ICT integrated in Nigerian pre-service teacher training in Nigerian Colleges of Education? What are the implications on social studies teacher training education and Nigerian National Policy on Education?

Thus, this review examines the implications of the current practices of ICT integration in Nigerian Colleges of Education as relate to: the goals and objectives of social studies education in Nigeria; the social studies pre-service teacher training program; the quality and relevance of the teacher-education program in Nigerian Colleges of Education; the goals of teacher education and the National Policy on Education. The review aims at providing meaningful insight on current research gaps requiring attention on technology integration in the subject area of social studies within the context of Nigerian Colleges of Education; and, to identify issues and questions of technical concern capable of motivating research studies that can help to improve the pedagogical designs of instructions in the subject area through ICT integration. The focus of this review is on ICT integration in Social Studies teacher education and the consequent implications of the present status on the quality and relevance of Social Studies preservice teacher training in the Nigerian Colleges of Education. Findings from this review would serve as a guide for meaningful reforms in line with the current challenges of teacher education in the present information age.

\section{The Review of Literature}

\subsection{ICT Integration and the Nigerian National Policy on Education}

Considering the influence of information technology in all sectors of the society [1]; the government and other stakeholders of the education industry in Nigeria consider the integration of ICT in the nation's educational system at all levels of learning a necessity [8]. This consideration was in recognition of: a. the prominent role of education as a 'viable instrument' for the attainment of national development [9];

b. the training and development of Nigerian youths into becoming responsible citizens, capable of contributing meaningfully to the socio-economic, political and the overall wellbeing of the society as adults [10];

c. The training and development of required manpower as desired by the society to man all sectors of the economy.

The government consideration for ICT integration in Nigerian educational practices is to empower and strengthen the competence of the education industry towards meeting up with these responsibilities [11]. Particularly, that of producing ICT literate citizens that can effectively fit into the contemporary information age where information technology has become an integral part of the society [2].

In pursuit of this consideration Federal Ministry of Education in conjunction with the National Educational Resource Centre (NERC hereafter) working on government directives introduces 'computer science' as a core and compulsory subject in Nigerian primary and junior secondary schools. Computer labs were built and equipped in most of the federal schools across the nation through the Education Tax Fund (ETF hereafter) intervention program. Candidates with Nigeria Certificate in Education (NCE hereafter) and specialisation in computer science were recruited to teach the subject in primary schools while university graduate with B Ed; B Sc. Ed and B Sc. (computer science) were recruited to teach the subject in junior secondary schools.

In Polytechnics, Colleges of Education and Nigerian Universities, 'introduction to basic computer knowledge' was introduced as a compulsory course unit for all students under general studies department. The course is meant to exposed students towards acquiring basic knowledge, skills and application of word processing; excel; access; and database management. Computer assisted instruction was introduced as a compulsory course unit in educational technology for all pre-service teachers in Nigerian Colleges of Education. Certificate in computer appreciation and application is made a compulsory requirement of promotion in addition to publication for all serving academic staff in Polytechnics, Colleges of Education and Universities; and a compulsory requirement for all candidates seeking employment as academics in all institutions of higher learning. From the 1990's, series of ICT standalone courses and workshops 
were organised and sponsored by federal and states government for teachers consistently.

Following these development, the government in 2004 come up with a revised edition of the National Policy on Education, incorporating the integration of ICT in education as part of the policy. The policy statement makes computer science a compulsory subject for all students in primary and junior secondary schools; making it a duty for the state governments and the private sector to make provisions for computer labs and equipment in all private and state owned schools as part of the accreditation requirement. The policy recognises the teaching of computer science as a necessary step towards ensuring that:

1. Pupils at the end of their three years of junior secondary education are competent in the use and application of ICT for personal and industrial use;

2. Students at the end of their studies acquire the needed information and ICT literacy skills as a solid foundation for the use of information technology in higher education.

The policy charges the department of secondary education (Federal Ministry of Education) and the National Commission for Primary Education with the responsibility of providing in-service training for school teachers. Such training is to be directed towards preparing teachers to integrate ICT in their pedagogical practices.

The policy makes it compulsory for academic staff in all institutions of higher learning to integrate ICT in their pedagogical practices. Emphasis is particularly made on the integration of ICT in teacher education programmes. The emphasis was to ensure that, pre-service teachers trained in Nigerian Universities and Colleges of Education acquire the contemporary skills and competence needed for teaching with technology in the present information age. Consequent of this policy, desk-top computers for office use and laptops were provided to academic staff in Federal Universities, Colleges of Education and Polytechnics in batches. Additional computer labs, cable and wireless internet services as well as elibraries were provided for students use by the respective management of the institutions, ETF and Petroleum Technology Development Endowment Fund (PTDF hereafter). Directives were given to private and state institutions to follow suite as requirement for accreditation. However, even with these resources and efforts, level of technology integration in Nigerian educational system at all levels is still very low [12].
Despite the facilities provided, school teachers are unable to integrate ICT in their educational practices and pedagogy [13]; [11]. And though, series of workshops on ICT in education were organised for teachers; yet, apart from the computer science teachers, most of the teachers lack the proficiency and competence needed for ICT integration in education [14]; [15]. Because of the incompetence, most of the teachers developed negative attitudes with little or no interest in the use of ICT [16]; [17]. The situation is more particular in rural schools owned by the state governments where access to some ICT facilities is limited with over $65 \%$ of the teachers having no interest in the use computer associated technology in their teaching and learning [13]. In this condition, actualising the goal of producing school leavers capable of utilising ICT in their higher education is likely to remain a mirage [1]; [11].

This situation is raising a serious concern over the credibility and competence of Nigerian schools towards actualising Nigerian philosophy of education; directed towards producing citizens with competent ICT skills that can function effectively in technology driven society of the information age [13]. The inability of the school teachers to use ICT in their pedagogical practices is associated with the poor state of technology integration in teacher education programme [11].

\subsection{ICT and Social Studies Education}

The teaching of social studies education is geared toward the development of self-thinking and creative individuals, imbued with innovative abilities of addressing their various personal and societal problems realistically [18]. Social studies education was introduced in Nigerian schools to equip the learner with information, knowledge, attitudes, skills and values that can help him to fit into the wider society [19]; [20]; [10]; [21]. The curriculum design of social studies education is therefore society centred, meant to sharpens the creative potentials of the learner in terms of creative thinking directed towards identifying societal problems while proffering solutions [15]. Would ICT integration have any effect in the teaching and learning of this subject design?

ICT integration in social studies instructions would facilitate and motivate learners' active involvement in the exploration of information that can be applied in solving real life problems [22]. As such, documented and programmed social studies instructions through the use of ICT would assist the learner in his learning process. This is because, relevant information, ideas, knowledge, learning experiences and thought provoking drills are 
disseminated for learners' consultation through the use of computer and the internet [23]. Use of ICT as instructional materials in social studies education facilitates students' achievement, creativity, and the development of higher order thinking [24]. This is because ICT as Instructional material use combination of text, sound videos that attract, engage and retain students' interest in learning [15]. The use of computer, internet, the smart board and web resources supports and enhance the teaching and learning of social studies education [25]. Thus, how prepared are Colleges of Education in Nigeria in the preparation of teachers capable of using ICT to advantage in their classroom teaching?

\subsection{State of ICT Integration in Nigeria and the Nigerian Colleges of Education}

Not much of digital technologies are used in pedagogical practices by teacher educators in Nigerian Colleges of Education and other institutions of higher learning. Most of the institutions do not have the necessary ICT facilities for instructions and research neither do teacher educators possess the needed skills and competence for effective integration of ICT in classroom instructions [26]. Level of ICT literacy among academic staff and students in Nigerian Colleges of education is still very low [27]. Most of the teachers in Nigeria at all levels do not have the needed experience and competence in the use of computers either for educational or industrial purposes; neither do they have the needed skills and knowledge in the use common computer software [11]; [1]. ICT education is more literary than it is practical in terms of physical use [28]. When teaching and learning is accessed critically in Nigerian Colleges of Education, it could be observed that the challenge for teacher educators is no longer in covering the course contents, but in having access to ICT and using it to enhance teaching and learning [1].

Colleges of Education and other institutions of higher learning in Nigeria are yet to fully integrate ICT in their teacher education programme [13]. Even though, the impact of ICT integration on students' achievement is highly appreciated by most educators [29], teacher educators hardly model the use of ICT in their pedagogical practices [6]. Classroom instructions in these institutions are still characterised with the use of conventional white boards and markers using the lecture oriented pedagogy. Hardly would the pre-service teachers see the teacher educators modelling the use of ICT tools in their classroom instructions. Even the lecturers handling the compulsory 100 ICT course and 'computer assisted instructions' as a course unit in Colleges of Education teaches the course using the conventional lecture approach more literally than practical without using technology [13]. With such pedagogical practices, translating the vision and mission of producing teachers with high level competence and proficiency towards the use of ICT in their teaching into reality as envisage in the National Policy may likely remain a mirage [11].

The success of the much needed ICT integration in schools depend largely on the teacher's level of ICT literacy [6]; [30], competence, self-efficacy [31]; [32] and interest [33]. Acquiring this competence by teachers on training depends on the quality and effectiveness of ICT integration in teacher education programme [11]. To ensure this competence, there is the need for effective ICT integration in teacher education curriculum and pedagogical practices [34]; [5]; [6]. This is lacking in Nigerian Colleges of Education [6].

\section{Methodological Approach}

This is a literature based conceptual study that employs the use of document-based qualitative approach. The data considered in this study were drawn from two major sources. The first source was the existing research works (literature) relating to ICT integration in education, ICT integration in teacher education, social studies education, social studies teacher education and technology integration in social studies teacher education; the second source was policy-documents relating to the same issues. The selection of literature and documents considered in the study were purely restricted to Nigeria, Singapore and the United State of America.

The decision to consider literature and documents from the United States of America was influence by the recognition that, social studies education as a subject originates from the United States; and the current structure of social studies education in Nigeria was modelled from that of the United States. While the consideration of Singapore-based policy documents and literature was influence by a consideration of the unique similarities between the Singapore teacher education and Nigerian teacher training programmes. In addition to this, United Nations documents relating to ICT integration in education was also considered. The data collected were analysed using content analysis approach.

\section{Findings and Discussion}

Findings from this study relating to ICT integration in education reveals that, integrating ICT in education can serve dual purpose. First, as an instructional aid that can facilitates pedagogical practices; and secondly as a subject to help learners' acquire the skills and competence of using digital technology in their personal and professional life. On 
the other hand, the findings also indicated that, integrating ICT in pedagogical practices by social studies teachers' and teacher educators in the teaching-learning process can exposed learners to unlimited learning content; and can motivates learners' active involvement in the exploration of data needed for problem. Meaning that, with digital technology learners can have direct contact with the learning content instead of getting the content from the teacher. Thus, if technology is effectively integrated, the role of the teacher would change from that of the giver to that of a facilitator in the learning process. This would lead to the development studentcentred activity oriented learning where the learners explore content and construe knowledge on their own with the teacher serving as a guide; therefore, promoting inquiry-based learning. Such changes in the learning process as can be facilitated by ICT integration would transform and align the learning process to the constructivist learning approach.

Secondly, the findings also indicated that utilising ICT in pedagogical practices as instructional aids in classroom teaching can enhance and facilitates teachers delivery of learning content; and improve learners achievement in understanding subject content. This is because with digital technology, teachers can make their presentations of subject content more concrete, interesting, entertaining and interactive using video, simulations and a lot of different software that goes a long well web 2.0 technology. Meaning that, learning can be more concrete than imaginary [35].

Thirdly, the findings indicated that, integrating technology in educational practices both as instructional aid in pedagogical practices and as subject can promote the development of ICT literacy and $21^{\text {st }}$ century skills. $21^{\text {st }}$ century skills is a household concept that integrates technological literacy with information literacy, problem-solving skills, higher order thinking, critical and reflective reasoning, collaboration, team work and decisionmaking; and the ability to apply them for problem solving in real life situation.

However, despite the possible advantages of ICT integration in education as discussed above, the findings of this study relating to the readiness of Nigerian Colleges of Education for effective ICT integration indicated that, much is still needed in Nigerian Colleges of Education. The level of technology integration in pedagogical practices and as a course is very low being more theoretical than practical. The low level of preparedness can be associated to two main issues; infrastructure and manpower development. Because, up to date ICT facilities in some of the colleges is lacking and grossly inadequate in some others; the level of ICT literacy and proficiency among the teacher educators is very low and theoretical (certificate-based), therefore most of the teacher educators lack the experience and competence of using computer associated facilities. Some of the implications of this situation in relation to social studies teacher education are discussed below.

\subsection{The Implications on Teacher Preparation and Social Studies Pre-service Teacher Training}

The lack of access to basic ICT equipment, low internet connectivity and computers and the inadequacies in the use of educational software have become a barrier to effective and professional development of teachers in Nigerian Colleges of Education [27]. It is most likely that the inability of Nigerian Colleges of Education to develop effective and proficient ICT literate teaching cadre may be the result of the corrupt practices of government officials crippling the institutions funding [36]; [27]. Lack of adequate ICT infrastructure in Nigerian universities and Colleges of Education has incapacitated government effort towards establishing valuable and effective teacher education programme to help in the preparation of teachers', competent enough to meet the challenge of the ICT era [27]. This situation implies that teacher educators and their students in Nigerian Colleges of Education would lack access to the electronic educational resources afforded through the use of ICT materials. Teacher educators would not be able to integrate ICT as instructional tools in their pre-service teacher training neither would they be competent enough to guide the pre-service teacher to acquire the skills needed for ICT integration in teaching [27].

Consequent of this situation, teacher educators in Nigerian Colleges of Education would lack the facilities and competence of developing ICT based project and activities especially design to raise the level of teaching in the subject area to improve students' achievement [37]. Inadequate teacher preparation of this nature may result in majority of teachers' inability to demonstrate adequate knowledge and understanding of modern pedagogical structures and designs of classroom instructions in their disciplines [1]. Thus, the quality of teacher training programmes provided by Nigerian institutions of higher learning as being hindered by the lack of effective use and provision of ICT instructional materials [7]. Thus there is a significant relationship between ICT usage and poor standard of teacher education which invariably affects the standard of the pre-service and in-service teacher performance [7]; [11]. 
Consequent of the above situation, teacher educators in Nigerian Colleges of Education might not be able to use ICT to help social studies preservice teachers to analyse teaching and learning or demonstrate models lessons nor could they be able to guide them in the utilisation of ICT productivity tools for words processing, grade and records keeping, web-page production and presentations [6]. A major concern of the social studies educator essentially impinges on a rational and integrative utilisation of knowledge resource from a large variety of sources for the purpose of improving the life of an individual and citizens alike and that of the society at large [10]. As evident in literature, the use of ICT can facilitates the attainment of this concern. Unfortunately, the present state of ICT facilities and integration in Colleges of Education would not permit social studies pre-service teachers to learn the practical use of ICT in teaching to this advantage. Since the qualities of social studies teachers trained through the Colleges of Education teacher training programme is not well equipped technologically to be able to face the challenges of carrying out their duties effectively. It implies that the existing curriculum designed for the training of social studies pre-service teachers does not include the practical usage of ICT materials. Even if it is included, it is only theoretical. As such pre-service teachers hardly come in contact with ICT instructional materials including those who are in the department of educational technology [27].

\subsection{The Implications on Social Studies Goals and Objectives}

The ultimate objectives of social studies program in Nigerian schools is the improvement of social living, not merely in the classroom but in the community, the nation and the world [38]. Since social studies education exposes the learner to immediate and distance social events in the social environment, the integration of ICT would help to concretised learning, motivates students' interest, and provide easy access to wide range of content materials that can improve instructions in the subject area [15]. But the poor state of ICT integration in Colleges of Education would be detrimental to preservice teachers' opportunity of learning to use ICT in their teaching for the attainment of these objectives. ICT provoke intense learning and sharpens learners' intellectual powers and their reflective thinking; and active learning situation is one of the noble objectives of instructions in social studies education [10]. Social studies teachers trained in Nigerian Colleges of Education would lack the skills and competence of utilising ICT in classroom instructions to this advantage.

Citizenship training which impliestransforming the school child into becoming a responsible citizen capable of contributing to the socio-economic and political development of his immediate environment and beyond; is the major goal of social studies education [15]; [10]. ICT integration can facilitates the attainment of this goal because ICT provide wide learning experiences which unifies knowledge in a manner to develop the individual in private, academic, public and business life [15]. More so, that the use of information technology has become an integral part of the human society, the social studies teacher must equip the school child with knowledge and skills that can help the child cope with challenges of the time. But, because of the poor ICT integration in Nigerian Colleges of Education; teachers competence in coping with this goal oriented task is lacking.

Social studies education as a curriculum design is meant to transform the school child into becoming a responsible citizen capable of contributing to the socio-economic and political development of his society and the world community. To achieve this, social studies teachers are expected to engage students in learning tasks that are problem solving oriented through the inquiry learning process. Through this process, the child would be exposed to: problem-solving skills; the inquiry process and skills; critical and reflective thinking; rationality, creativity and objectivity in decision making. Existing studies reported that, use of relevant ICT materials proved effective in facilitating students' achievement in respect of the above mentioned objectives. Poor ICT integration in Nigerian Colleges of Education is a responsible factor for the poor standard of teacher education in Nigeria; and the consequent inability of social studies teachers in schools to effectively attain the objectives and goals intrinsic in the subject area [7]; [11]. This state of affairs in the Colleges of Education was largely responsible for the failure of the ICT integration programme in Nigerian Secondary schools. This was because the teachers to implement the programme had no knowledge ICT integration in teaching and learning; neither were they exposed to it during their teacher training programme in the Colleges of Education [11]; [27].

\section{Conclusions}

ICT literacy and $21^{\text {st }}$ Century Skills is gradually becoming an integral part of the educational domains in the present information age; therefore, introducing additional dimension to educational objectives. There is the need therefore for teaching and learning 
at all levels to be directed toward the attainment of this emerging goal in addition to existing goals and domains associated with content learning and skills acquisition. Thus, based on issues emerging from this study, it was concluded that there is the need for ICT integration both as instructional aid and also as a course of study in every educational system.

As indicated in the findings of this study, integrating ICT in the teaching-learning process can facilitates teachers' efficiency in teaching subject contents and skills while facilitating students understanding and achievement in the learning process. It can also make the teaching-learning process activity oriented, student-centred, and inquiry based. Therefore, promoting the development of $21^{\text {st }}$ century skills that is much needed to survive the challenges of living in the emerging knowledge societies.

However, the success of ICT integration in the teaching-learning process is dependent on teachers' level of ICT proficiency. Therefore, to prepare teachers for this, there is the need for effective and innovative use of this technology in teacher training. Teacher training institutions must therefore consider the need of producing new breed of teachers with high level of ICT proficiency as a necessary challenge for the education industry to live up to expectations in the current dispensation.

Stakeholders of the education industry needs to understand the critical role of teacher education in producing the desired teachers needed for effective ICT integration in schools and other institutions of learning. There is also the need for policy makers to understand the connectivity and interdepended correlation of ICT integration, social studies education, $21^{\text {st }}$ century skills, and ICT literacy and competence in moulding young learners into becoming the desired citizens needed in the knowledge driven economies. To prepare teachers for ICT integration, the teacher training institutions need to fully and adequately equip with need ICT facilities that should be constantly upgraded to meet up with the increasing changes and development in digital technologies. Sufficient technicians need to be employed for the maintenance of the equipment; and teacher educators need to be constantly up-dated with the knowledge and skills of using the emerging technologies for educational purposes. Lecture hall, laboratories and venues of teaching and learning in the institutions needs to be provided with multimedia systems and overhead projectors that should be permanently fixed. ICT courses curriculum need to be flexible to accommodate the rapid changes in technological development.

\section{Reference}

[1] S. A. Onasanya, R. A. Shehu, R. O. Oduwaiye \& L. A. Shehu, "Higher Institutions Lecturers' Attitudes towards Integration of ICT into Teaching and Research in Nigeria", Research Journal of Information Technology, http://scialert.net/qredirect.php, 2010, pp. 1-10. (Access date: $17^{\text {th }}$ March, 2012).

[2] P.O. Nwachukwu, "Appraising the Relationship between ICT usage and Integration and the Standard of Teacher Education Programmes in Developing Economy", International Journal of Education and Development using ICT",

http://ijedict.dec.uwi.edu/viewarticle.php?id=194\&layout= html, 2006, pp. 20-24 (Access date: $20^{\text {th }}$ October, 2012).

[3] F. Larose, R. David, I. Derand, T. Karsenti, V. Vincent Grenon, S. Lafrane \& J. Judith Cantin, "Information and Communication Technologies in University Teaching and in Teacher Education: Journey in a Major Quebec University Reality", Electronic Journal of Sociology,http://www.sociology.org/content/vol004.003/fr ancois.html, 1999, pp. 1-16. (Access date: $11^{\text {th }}$ January, 2012).

[4] UNESCO, "Manual for Pilot Testing the use of Indicators to Assess Impact of ICT use in Education", http://www.unescobkk.org/education/ict/resources, 2003. (Access date: $11^{\text {th }}$ January, 2012).

[5] T. Teo, "Pre-service Attitudes towards Computer use: a Singapore Survey," Australian Journal of Educational Technology, vol. 24, No. 4, 2008, pp. 413-424.

[6] C. Bolick, M. J. Berson, C. Coutts \& W. Heinecke, "Technology Application in Social Studies Method Faculty", Contemporary Issues in Technology and Teacher Education, www.citejournal.org/article/v3i3, 2003, vol. 3. No. 3, pp. 300-309. (Access date: $13^{\text {th }}$ December, 2012).

[7] N. P.Ololube, "Bench Marking the Motivational Competencies of Academically Qualified Teachers and Professionally Qualified Teachers in Nigerian Secondary Schools" African Symposium, 2005, vol. 5. No. 4, pp. 1731.

[8] F. R. Nigeria, National Policy on Education, NERDC Press, Lagos-Nigeria, 2004.

[9] F. R. Nigeria, National Policy on Education, NERDC Press, Lagos-Nigeria, 1998.

[10] C. C. Okam, Reading in New Developments in Nigerian Education: Issues and Insight (A Collection of Curriculum Papers), Deka Publications, Jos, Nigeria, 2002.

[11] M. A. Yusuf, "Information and Communication Technology (ICT) and education: analysing the National Policy on Education," International Education Journal, 2005, vol. 6, pp. 316-321. 
[12] I. J. Abba, "ICT in Distance Education: The way forward", Journal of Educational Media and Technology, 2012, vol. 16. No. 1, pp. 131-134.

[13] T. O. Adeyemi \& F. O. Olaye, "Information Communication and Technology for effective Management of Secondary Schools in Ekiti State, Nigeria, AmericanEurasian Journal of Research, 2010, vol. 5. No. 2, pp. 106-113.

[14] D. Magawata, F. Muhammad \& F. A. Ahmad, "elearning and Distance Education in Achieving Sustainable Development in Nigeria, Sardauna Journal of Multidisciplinary Studies, 2011, vol. 2. No. 2, pp. 309-313.

[15] D. I. Mezieobi, "Actualising the Social Studies Curricular in Nigerian Secondary Schools through the Instrumentality of Information Communication Technology", Information Communication Technology for the Service of Education, 2008, retrieved from: www.unn.nig doi: www.unn.edu.nig/home/index2.php?option=com_docman $\&$ task=doc_view $\&$ gid $=7274 \&$ itemid=306

[16] B. E. C. T. Agency, "A review of the research literature on barriers to the uptake of ICT by teachers", retrieved from http://www.becta.org.uk

[17] K. Hara, "Teachers Attitudes toward Information Skills", Education Libraries Journal, 1999, vol. 42. No. 2, pp. 5-14.

[18] A. E. O. Esu, M. A. Inyang-Abia, Social Studies Technologies, Methods and Media, Double Diamond Publications, Port-Hercourt, Nigeria, 2004.

[19] E. O. Osakwe, "Social Studies and Nation Building in Nigeria: which way in the $21^{\text {st }}$ Century", Social Studies Quarterly, 1997, vol. 1. No. 1, pp. 8-12.

[20] A. E. O. Esu \& O. P. Dania, "Educators Perception and Attitudes towards Social Studies Implementation in Nigeria”, Social Studies Quarterly, 1999, vol. 2. No. 3, pp. 1-6.

[21] D. I. Mezieobi, "The Place of Social Studies in the Socio-cultural Education of the Edo People", Nigerian Journal of Research, 2005, vol. 6. No. 2, pp. 147-166.

[22] F. N. Okoye \& G. B. Udegbe, "The Need for ICT in Science Education: Teachers' Perspective", Paper Presented at the Annual National Conference on ICT and Enhancement of Education in the $21^{\text {st }}$ Century held at Federal College of Education (Technical)Umunze, Anambra State, Nigeria, 2004.

[23] A. E. O. Esu, O. I. Emukoha \& G. U. Umuren, Curriculum Development in Nigeria for Colleges and Universities, But-Bass (Nig), Calabar, 1998.
[24] B. A. Ogboji, "Utilization of Information and Communication Technology (ICT) in Graphic Communication in Tertiary Institutions: Implication for Development, Implementation and Evaluation", Paper Presented at the Annual National Conference of Institute of Education on Information and Communication Technology in the Service of Education, University of Nigeria Nsuka, Institute of Education, 2006.

[25] G. C. Offorma, "Curriculum Issues in the $21^{\text {st }}$ Century" A Keynote Address Presented at the $2^{\text {nd }}$ Annual Conference of Curriculum Organisation of Nigeria, Held at Cross Rivers State University of Technology, Calabar, Nigeria, 2006.

[26] O. A. Agbatogun, "Attitudes of Teachers' towards the Integration of Computer Education into Secondary Schools Curriculum" Journal of Research and Curriculum Teaching, 2006, vol. 1. No. 1, pp. 1-20.

[27] N. P. Ololube, "Teachers' instructional materials utilisation competencies in secondary schools in Subsaharan Africa: professional and non-professional teachers' perspectives," Proceedings of the $6^{\text {th }}$ International Educational Technology Conference, Emu, North Cyrus, April, 2006.

[28] P. O. Nnabuo \& F. N. Obasi, "Effective use of Information Technologies (IT) Device Enhancing Development (HRD) in Educational Institutions in Nigeria”, Journal of Curriculum Studies, 2004.

[29] I. N. Umar \& S. Maswan, "The effect of web based guided Inquiry on Students Achievement" Journal of Computers, 2007, vol. 2. No. 5, pp. 38-43.

[30] F. Paraskeva, H. Bouta \& H. Papagianni, "Individual Characteristics and Computer Self-efficacy in Secondary Education Teachers to integrate technology in education practices", Journal of Computers and Education, 2008, vol. 50. No. 3, pp. 1084-1091.

[31] D. Brown \& M. Warscchauer, "From the University to the Elementary Classroom: Students experiences in Learning to Integrate technology in Instruction" Journal of Technology and Teacher Education, 2006, vol. 14. No. 3, pp. 599.

[32] W. J. Pelgrum, "Obstacles to the integration of ICT in Education: Result from a worldwide educational assessment", Computers and Education, 2001, vol. 37, pp. 163-178.

[33] D. P. Ely, "Technology is the answer! But that was the question?", Paper presented at the James P Curtis Distinguished Lecture, College of Education, University of Alabama, 1995.

[34] C.P. Lim, C. S. Chai, D. Churchill \& M. Partners-inlearning, Leading ICT in Education Practices: A Capacity Building Toolkit for Teacher Education Institutions in the 
Asia-Pacific, 2010, Microsoft Partners in Learning AsiaPacific.

[35] P. Mishrah \& M. Koehler, "Technological pedagogical content knowledge: a framework for teachers knowledge," Journal of Teachers' College Records, 2006, vol. 108, No. 6, pp. 1017-1054.

[36] A. U. Osunde \& F. E. O. Omoruyi, "An Evaluation of the National Teachers Institute Manpower Training for Teaching Personnel in Mid-Western Nigeria", International Educational Journal, 2004, vol. 5. No. 3, pp.405-409.

[37] S. E. Aduwa-Ogiegbaen \& E. O. S. Iyamu, "Using Information and Communication Technology in Secondary Shcools in Nigeria: Problems and Prospects", Journal of Education for Teaching, 2005, vol. 31. No. 2, pp. 99-110.

[38] G. W. Joof, Trend in Curriculum Development in Social Studies and the Social Sciences, White and White Publishers, Owerri, Nigeria, 1994. 